\title{
RURAL SETTLEMENTS ON PEATLANDS IN MOSCOW REGION: IMPACT OF ECONOMIC ACTIVITIES AND CLIMATE CHANGES ON QUALITY OF LIFE
}

Tatiana Borodina ${ }^{1}$, Alexander Savchenko ${ }^{2}$

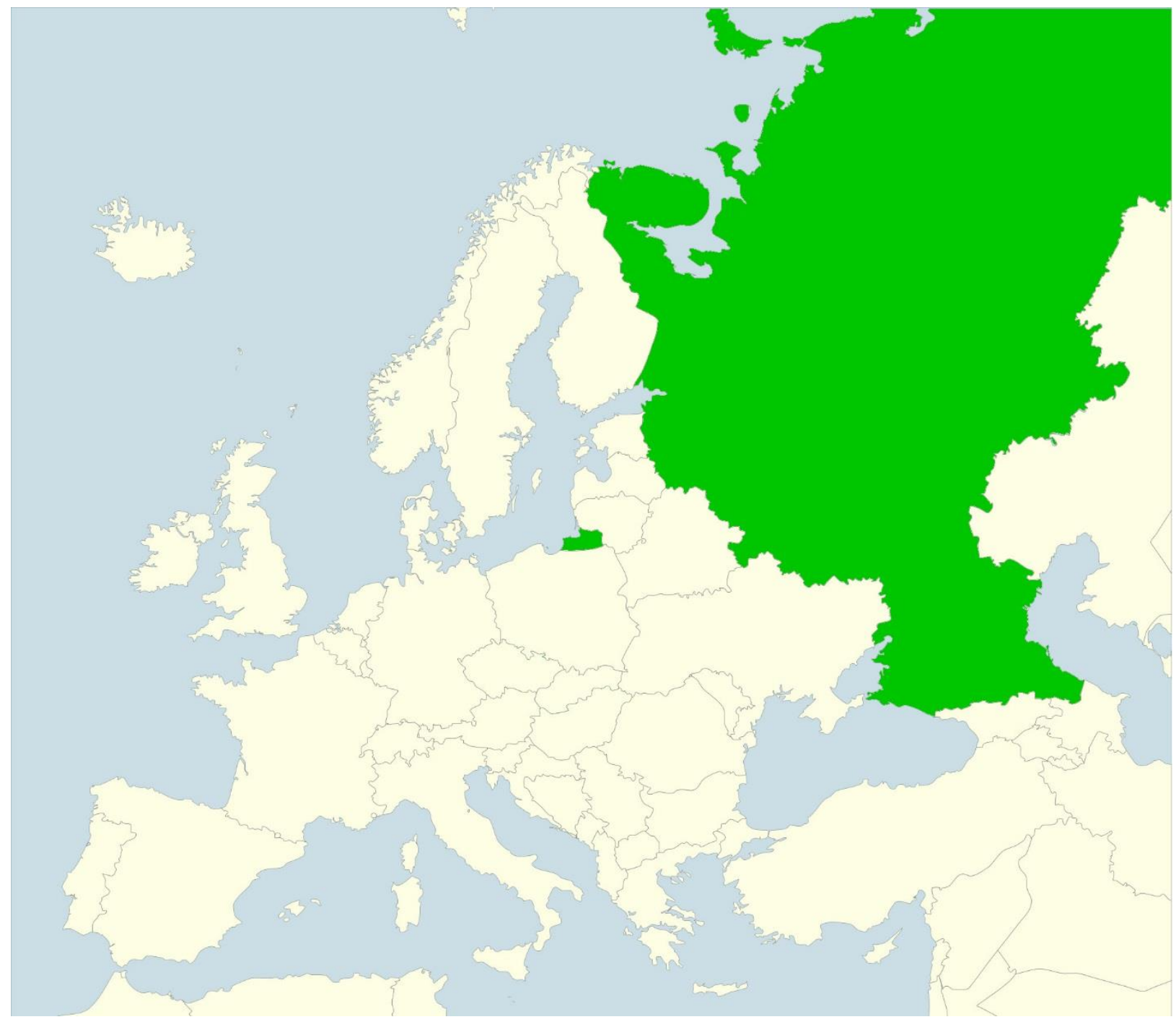

\footnotetext{
1 Dr. Tatiana Borodina, Senior Researcher, Institute of Geography, Russian Academy of Sciences, Staromonetniy Pereulok, 29, Moscow, Russian Federation 119017. E mail: borodina_tl@mail.ru.

2 Prof. Alexander Savchenko, Director of Center for Situational Monitoring and Regional Studies, The Russian Presidential Academy of National Economy and Public Administration, 82/5, Prospect Vernadskogo, Moscow, Russian Federation 119571.E mail: savchenko_alex@mail.ru
} 
Abstract: The impact of the transformation of economic activities and sharp weather and climate changes on the quality of life in rural settlements on peatlands in the Moscow region was analyzed. As theoretical background, an analysis of various interpretations of the concept of the quality of life was carried out, including in the context of sustainable development. The impact of economic and environmental factors of the quality of life in rural settlements on peatlands is considered with respect to their location in the zone of attraction of Moscow. It was concluded that the development of industrialization in the region led to population decline and to increase in the anthropogenic load. This critically increased the vulnerability of peatlands to fluctuations in weather and climate conditions and several times led to serious environmental disasters. At the same time, location in the zone of attraction of Moscow opens up opportunities for improving the quality of life associated with the development of post-industrial recreational use.

Key words: quality of life, peatlands, economic activity, weather and climate changes, rural settlements, Moscow region

Аннотация: На примере Московского региона статья анализирует влияние трансформации хозяйственной деятельности и резких погодно-климатических изменений на качество жизни на торфяниках. В качестве теоретической базы проводится анализ различных трактовок концепции качества жизни, в том числе в контексте представления об устойчивом развитии. Влияние экономических и экологических фракторов качества жизни сельских поселений на торфяниках рассматривается с учетом расположения в зоне влияния Москвы. Делается вывод, что развитие индустриализации в регионе привело к сокращению населения и росту антропогенной нагрузки. Это критически увеличило уязвимость торфяников от колебаний погодно-климатических условий и несколько раз приводило к серьезным экологическим бедствиям. Вместе с тем, именно пребывание в зоне притяжения Москвы открывает в настоящее время возможности повышения качества жизни, связанные с развитием постиндустриального рекреационного использования.

Ключевые слова: качество жизни, торфяники, экономическая деятельность, погодноклиматические изменения, сельские поселения, Московский регион.

\section{Introduction}

Frequent summer forest fires in Portugal, Spain, Italy and Greece can give a reason to consider coniferous forests of the subtropical zone of Europe as the most vulnerable to the resilient and sustainable development of mainly rural settlements located there. The cause of these fires are sharp weather and climate fluctuations, which are a demonstration of climate warming, and sometimes excessive anthropogenic load, also caused by the active development of tourism in the course of globalization.

In 2017, the number of forest fires in the EU has more than doubled so far, according to figures obtained by Euronews, affecting an area twice the size of Luxembourg. There have been 1,671 blazes so far in 2017 - a huge increase on the 639 the bloc saw annually on average over the previous eight years. Experts have blamed climate change for the rise, saying it has extended the traditional wildfire season and increased the frequency of blazes. They have warned Europe's forest fires will rage more often in the future and engulf new areas. Portugal, Italy and Croatia have all been hit this summer amid high temperatures and lower-than-normal rainfall. 64 people died in a forest fires in Portugal (Climate change, 2017). In the summer of 2017 wildfires are also raging in parts of central and southern Europe in Croatia, Montenegro, France (Wildfires rip through southern and central Europe, 2017) and in California in the USA (Deadliest wildfires in California, 2017). 
However, in Europe "to the North of the Alps", there is a widespread type of rural areas, also located in a zone of high risk: peatlands which stretch from Ireland to the Urals through Holland, Germany, Poland, Scandinavia, and the Baltic States. Peatlands provide globally important ecosystem services through climate and water regulation or biodiversity conservation. While covering only $3 \%$ of the earth's surface, degrading peatlands are responsible for nearly a quarter of carbon emissions from the land use sector (Bonn, Allott, et al., 2016). Peatlands are a characteristic type of landscape in the Moscow region, there are a lot of different rural settlements there and a number of aspects of sustainable and resilient development of settlements on peatlands will be considered using the example of the impact of the transformation of economic activities and weather and climate changes on the quality of life of rural settlements on the peatlands in Central Russia.

Research objective of this paper is to assess at a qualitative level in a long-term retrospective the impact of the transformation of economic activity and sharp weather and climate fluctuations on the quality of life of rural settlements on peatlands, taking into account their location in the zone of influence of a large urban center.

\section{Theoretical background}

"Quality of life" can be defined as the general well-being of the people living in a society. QOL is a complex concept that incorporates many different material and immaterial aspects. It refers to the general well-being of people, groups or societies, and has been used widely within e.g., healthcare, policy and international development. It should be emphasized that QOL does not simply refer to income-related living standards of individuals (the economic aspect), but is a wider concept that also includes the surrounding environment, physical and mental health, education, leisure, recreation, social belonging, and so forth (Nussbaum, Sen, 1993; Gregory et al., 2009).

Quality of life is a broad concept that encompasses a number of different dimensions. It encompasses both objective factors (e.g., command of material resources, health, work status, living conditions and many others) and the subjective perception one has of them. The latter depends significantly on citizens' priorities and needs. Measuring quality of life for different populations and countries in a comparable manner is a complex task, and a scoreboard of indicators covering a number of relevant dimensions is needed for this purpose. (Quality of life indicators, 2017). Quality of life is the degree of satisfaction of material, spiritual and social needs of a person. National accounts aggregates have become an important indicator of the economic performance and living standards of a society. This is because they allow direct comparisons to be made easily. Gross Domestic Product (GDP), one of these aggregates, is the most common measure of the economic activity of a region or a country at a given time; many decision and policy makers use it as the standard benchmark, often basing their decisions or recommendations on it. It includes all final goods and services an economy produces and provides a snapshot of its performance. GDP is very useful for measuring market production (expressed in money units). However, although it was not intended as an indicator of social progress, it has been considered to be closely linked to the well-being of citizens. The following are a number of reasons why GDP is not sufficient for this purpose, and therefore needs to be complemented by other indicators (Quality of life indicators, 2017). Standard indicators of the quality of life include not only wealth and employment but also the built environment, physical and mental health, education, recreation and leisure time, and social belonging (Gregory et al, 2009).

Transition to a post-industrial society is accompanied by increasing attention to the non-material aspects of the quality of life. While GDP is very useful for measuring market production and providing an indicative snapshot of an economy at a given time, it does not provide a comprehensive picture of how well-off the citizens of a society are. As described in 2009 in the J. Stiglitz, A. Sen and J. P. Fitoussi Report by the Commission on the Measurement of Economic Performance and Social Progress (Stiglitz, 2009) citizens' material living standards are better monitored by using measures of household income and consumption. Authors argue that the income of a country's citizens is 'clearly more relevant for measuring the well-being of citizens' than domestic production. 
GDP and other economic measures need to be complemented with indicators covering other important dimensions in order to measure well-being. In order to compare countries on the standards and quality of life, the UN has developed an aggregated Human Development Index (HDI), that is composite statistic (composite index) of life expectancy, education and per capita income indicators. HDI can also be calculated for regions.

Organization for Economic Cooperation and Development (OECD) has proposed Better Life Index, that allows to compare well-being across countries, based on 11 topics the OECD has identified as essential, in the areas of material living conditions and quality of life: Housing, Income, Jobs, Community, Education, Environment, Civic Engagement, Health, Life Satisfaction, Safety, Work-Life balance (Better Life Index, 2017).

Recent statistics on the quality of life in the European Union (EU) propose the following dimensions of Quality of Life ("8+1") (Quality of life indicators, 2017):

- Material living conditions (income, consumption and material conditions)

- Productive or main activity

- Health

- Education

- Leisure and social interactions

- Economic and physical safety

- Governance and basic rights

- Natural and living environment

- Overall experience of life.

In Europe, enhancing the quality of life in rural areas and promoting diversification of economic activities is one of the three major objectives of the Rural Development policy (RDP) along with increasing the competitiveness of the agricultural sector and enhancing the environment and countryside through support for land management. Indeed, in the 2007-2013 RDP, the central objective of enhancing the quality of life in rural areas is to "have a 'living countryside' and to help maintain and improve the social and economic fabric" (Fact Sheet EU Rural Development policy, 2008), and particularly so in areas prone to depopulation (Brauer, Dymitrow, 2014). Rural areas are very diverse across Europe with different problems, challenges, approaches and priorities. The richest countries in the European Union show little evidence of significant urban-rural differences, whereas in the poorer countries of the east and south, rural areas have a much lower level of perceived welfare and quality of life, particularly in the candidate countries (Shucksmith et al., 2009). In the richest countries, for example in the UK, if you live in rural areas - you are more likely to have a greater quality of life. Those who live in rural locations are healthier, wealthier and more educated (The Facts: Rural vs Urban Living in the UK, 2017). A set of indicators that different researchers use to assess the QOL may vary, including distinctions between Quality of Life (QOL) and the Quality of the Living Conditions (QLC) (D'Agostini, Fantini, 2008), for different countries and regions with differing levels of socioeconomic development (Pospěch et al, 2009; Boncinelli et al, 2015).

Rating Agency RIA Rating of Media Group MIA "Russia Today" every year makes the rating of Russian regions for the quality of life. In 2016, the agency's experts used 72 indicators, which are grouped into 11 groups, which characterize all the main aspects of the living conditions in the region, from the level of economic development and income to the provision of the population with various types of services and climatic conditions in the region of residence. 
Eleven groups include (Life-2016):

1. Income level of the population

2. Population employment and labor market

3. Housing conditions of the population

4. Security of residence

5. Demographic situation

6. Ecological and climatic conditions

7. Health of population and level of education

8. Providing social infrastructure facilities

9. Level of economic development

10. Level of development of small business

11. Land developing and development of transport infrastructure.

Environmental and climatic conditions in the Russian regions are assessed on the basis of the following indicators:

- Emissions of pollutants into the atmosphere from stationary and mobile sources per unit area of settlements;

- Climate assessment;

- Providing the population with drinking water that meets the safety requirements;

- Ambient air costs per unit of emissions.

As can be seen, there are different approaches to the assessment of the quality of life indicators, taking into account different characteristics, both objective and subjective.

In this paper, we will not measure the quantitative parameters of the quality of life, but try at a qualitative level to track the impact of changes in economic activity and settlement pattern on the quality of life in settlements on peatlands in the Moscow Region, taking into account sharp weather and climate fluctuations. We have used the historical-geographical and genetic methods to identify interrelated changes in the aggregate of conditions and events that affect the QOL.

The assessment of the quality of life is closely connected with the concept of sustainable social and economic development of society aimed at the harmonious development of society, taking into account economic, social and environmental factors (Sustainable .development, 2017).

\section{Methodology and area under study}

Research objectives of this paper determine the choice of historical and geographical approach as the main topic. The topic is considered in the context of the concept of the rural-urban continuum: economic activities in rural settlements on peatlands - especially peat extraction often were carried out for fuel needs of surrounding cities. Consequences make these territories particularly vulnerable to modern sharp weather and climate fluctuations. This is especially true for the Center of Russia, where Moscow has constantly expanded the range of its influence in various aspects.

In the 1920s, American sociologists P. Sorokin and C. Zimmerman put forward the idea of Ruralurban continuum (Sorokin, Zimmerman, 1929). The term rural-urban continuum came into existence because of the fact that a marked difference between the urban and rural character is not seen in the settlements abutting the city limits. On one hand, they have characteristics of the city because of their closeness to it and on the other they cannot deny their rural characteristics of largely unplanned development.

In fact, we see a variety of transitional forms between them in terms of population, density of population, occupations, etc.

Economists and sociologists have used the concept of rural-urban continuum to stress the idea that there are no sharp breaking points to be found in the degree or quantity of rural urban 
difference. Modern analysis of the concept of "urban-rural continuum", including in relation to the realities of modern Russia was recently proposed by A. Treivish (2016).

With increasing population mobility and the emergence of many transitional forms between city and countryside in the course of the processes of urbanization, suburbanization, desurbanization, etc., it is often difficult or nearly impossible to draw a clear divide between urban and rural areas (Brade, Kovacs, 2014). During the process of urbanization, cities grow and urban life spread to the surrounding countryside. At the same time, we see the increasing desire of urban dwellers to escape from the "urban jungle" into nature, which is reflected in the development of various forms of recreation, including agri-tourism, the desire to have an exurban home for rest and/or gardening (traditional Russian "dacha").

Another context for the consideration of the topic is sustainable development (SD): its three main aspects - economic, environmental and social - cover all aspects of the topic, respectively, changes in the nature of economic activities on peatlands, changes in weather and climate conditions, changes in the quality of life in rural settlements. The context of SD in considering the topic in its most modern version is particularly evident from the standpoint of 17 goals of sustainable development of the UN until 2030, adopted by the General Assembly in 2015 (Sustainable development, 2017).

The Moscow region was chosen as an area under study. Moscow has always been the center of attraction of the surrounding areas and it can be said that the rural-urban continuum was formed here at least since the 18th century.

\section{Development of peat industry}

Since ancient times, peatlands have been considered as "neudob'ya" (lands, unsuitable for agriculture): they were suitable at best for gardening and haymaking, but were mainly used for gathering (cranberries, cowberries, bilberries, mushrooms) and hunting. It is not surprising that the territories of the extensive spread of peatlands from the late Middle Ages were relatively overpopulated - their population often received basic incomes not from agriculture proper the land fed poorly - but from "otkhodnichestvo" - non-agricultural activities which were often far enough from their native places, in our case Moscow was the main center of attraction and earnings (Fedorov, 1976). Historical changes of the density of the rural population of the center of Russia you can see at the scheme at Fig.1.
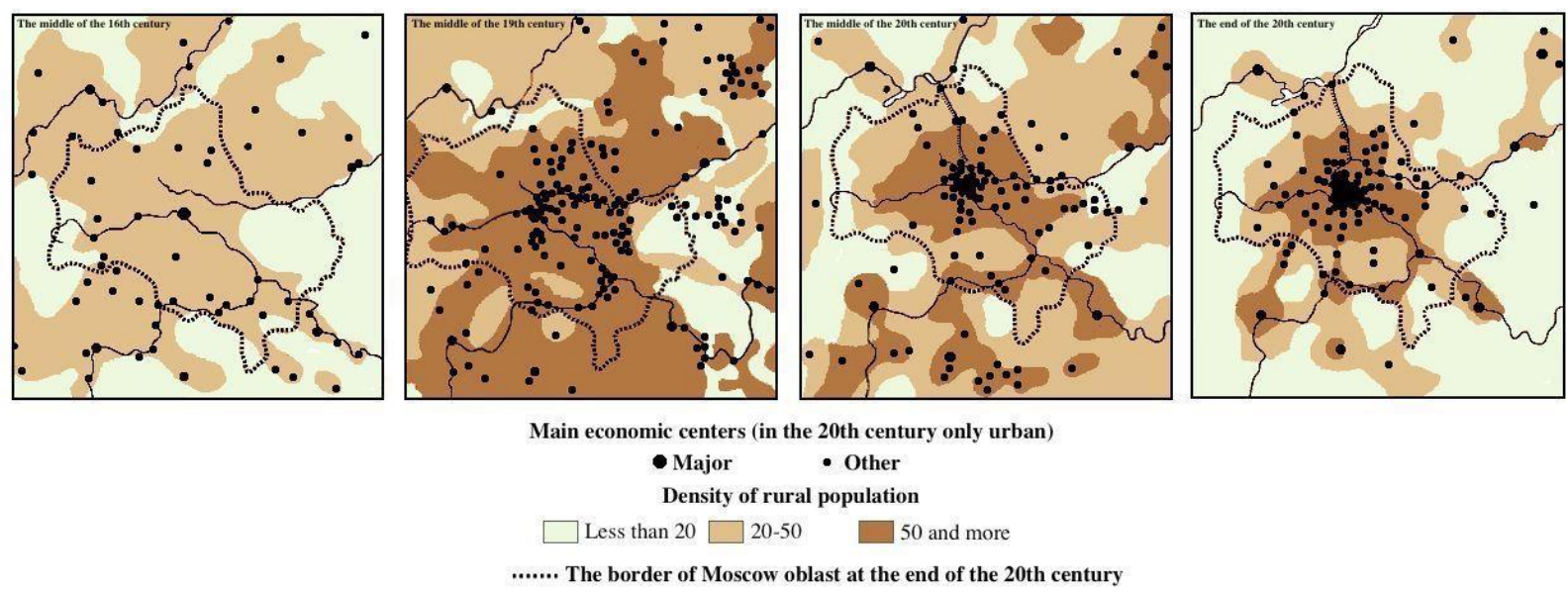

Fig 1. Evolution of settlement pattern in the center of Russia. Source: Treivish (2009)

With the development of market, manufactories, and then factories, especially since the end of the 18th century, this process only intensified and the seasonal migration covered the entire center of Russia. In this process, regions with vast peatlands - Tver, Vladimir, Yaroslavl provinces were the leaders. It should be noted that the density of the rural population in this region reached its maximum in this historical period - in the middle and the end of the $19^{\text {th }}$ century (Fig. 1). 
Quantitative estimates of the scale of seasonal labor migration in the middle of the XIX century from the provinces of peatlands are as follows: Tver - 191398 people or $30 \%$ of the male population, Vladimir - 87768 people or $22 \%$ of the male population, Yaroslavl - 105887 people or $26 \%$ of the male population. The leader in the volume of seasonal labor migration, of course, is the nearest Moscow Province $-204,266$ people or $36 \%$ of the male population (Fedorov, 1976).

In parallel with the development of seasonal labor migration, which covered all parts of the center of Russia from the end of the $18^{\text {th }}$ century, with Moscow as the center of attraction; another process was constantly gaining strength. Growing manufactories, and then factories, needed fuel, and in ever increasing volumes. The government encouraged the development of industry, but tried to save state forests that occupied a significant part of the Moscow province (the scheme at Fig. 2), although the supply of firewood to Moscow along the Moscow river system - the Moskva river and its tributaries - was very significant - tens of thousands of peasants from the western part of Moscow province were engaged in this business (Fedorov, 1976).

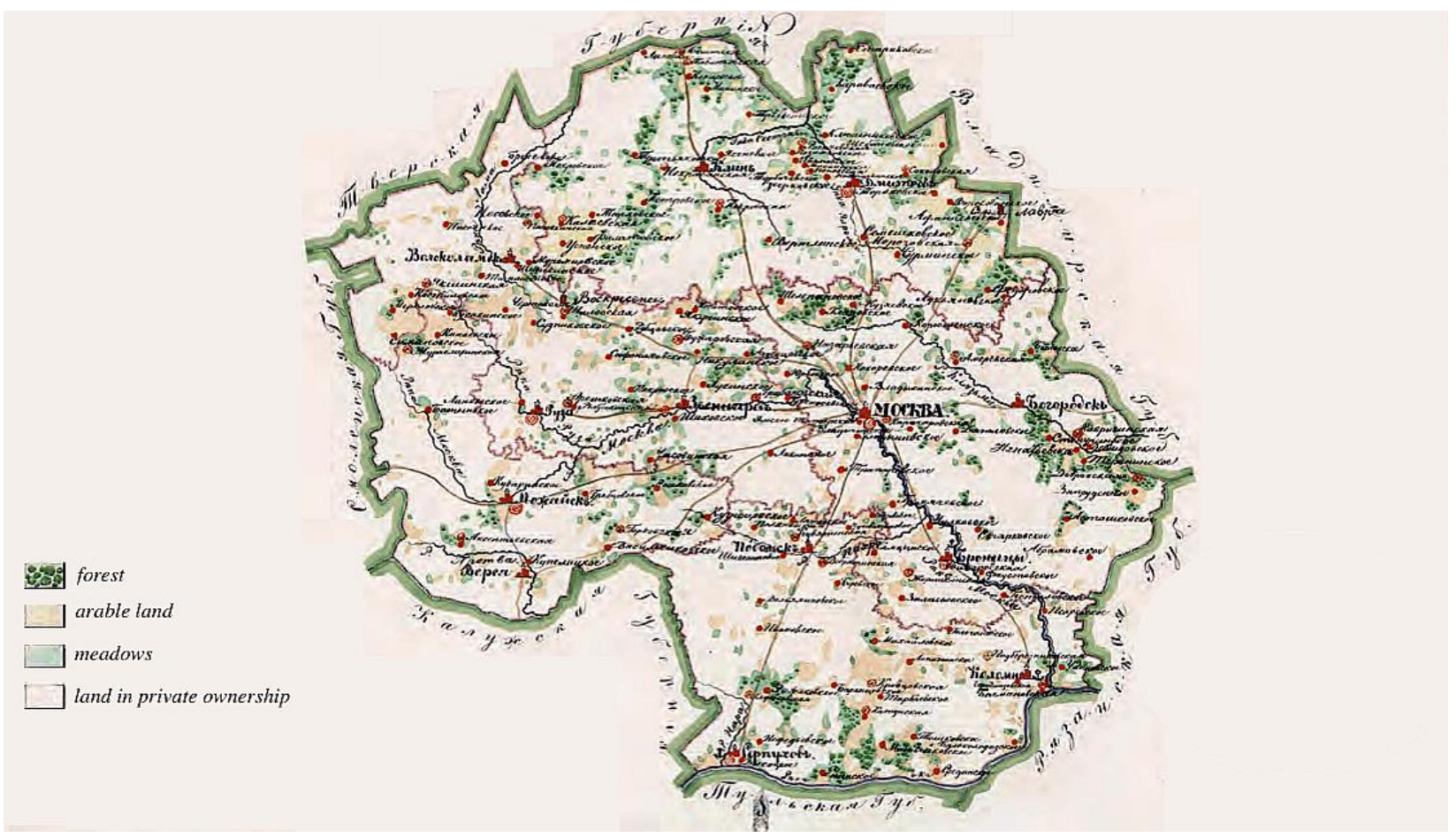

Fig 2. State property lands in Moscow Province in 1843. Source: Savchenko (2013)

Industrial development needed available alternative to firewood and peat got it from the mideighteenth century, particularly in areas where peatlands are combined with a convenient waterway for transporting of imported raw material (primarily along the Klyazma river) or with clay deposits suitable for faience and porcelain production in Gzhel and Verbilki, or quartz sand for glass production in Klin. Peat extraction in combination with the development of local industry significantly increased the incomes of the population of surrounding rural settlements, contributed to their growth and development, and improved the quality of life.

Sometimes villages grew so large that they even received the status of towns, for example Rogozha village on the banks of the river Klyazma received the status of the city and the new name Bogorodsk in 1781 (in 1930 the Bolsheviks renamed it in Noginsk and the town has this name till now). It should be noted that already in the middle of the 18th century, Rogozha village and then Bogorodsk was the local center of a whole constellation of handicraft villages, where weaving in the form of a scattered or centralized manufactory (and in the 19th century - textile factories) was the main occupation of the population. Peatlands did not leave a choice in the main occupations of the local villagers. This is the most vivid and happy example, when peat extraction and in this case textile production contributed to the development of the surrounding countryside, improving the quality of rural life. 
By the end of the $19^{\text {th }}$ century, due to the development of common economic and technological conditions, two new, in many respects alternative, tendencies of development of peatlands and settlements on them emerged. Initially, both of them were realized in the very center of the region under consideration - in the swampy Meshchera lowlands between the rivers Klyazma in the north, Oka in the south, the Moskva's lower stream in the west and Sudogda in the east.

Firstly, the group of entrepreneurs decided to introduce into the wide agricultural use, significant amounts of Meshchera lands, earlier often unused due to waterlogging, and financed a largescale land-reclamation expedition with the purpose of finding the route of an extensive main drainage canal. The exploration work was carried out and the construction was started, but finished already after the Revolution of 1917 (Marshev, 2011).

Secondly, the success of technologies provided the production and transmission of electricity in August 1915 from the station "Elektroperedacha" in Bogorodsk, (the world's first large power plant that worked on peat) to Moscow. The power line with the voltage of $70 \mathrm{kV}$ and length of about $70 \mathrm{~km}$ connected power plants in the Moscow region and in the center of Moscow (Serebryanikov, 1998). The era of peat electricity began.

The Bolsheviks took advantage of a successful example and made peat electricity one of the cornerstones of their first electrification plan for Soviet Russia. Already at the end of November 1917, the decision of building a powerful power station on Shatura peat $120 \mathrm{~km}$ from Moscow and about $50 \mathrm{~km}$ from Bogorodsk was made. This station, despite all the difficulties of the civil war, already began to work in 1920. This was already allowed in 1923 to consume electricity in Moscow and the suburbs more than in the record pre-revolutionary year 1916. Since the 1920s, the accelerated development of peat energy began in the USSR and, at first in the center of Russia - the production of fuel peat was constantly growing and in 1940 amounted to 33.2 million tons (conditional humidity), in 1977 - 41.2 million tons (Soviet encyclopedic dictionary, 1979).

At the same time, restructuring of the electric power industry - the transition to natural gas and fuel oil - negatively affected the peat industry and since the late 1970s, it began to collapse. The final point in its development was the collapse of socialism and the transition to a market economy in which the peat energy industry - at least in the form in which it was inherited from the USSR - was not competitive at all.

\section{Structural crisis and fires}

During the Soviet period, at the time of the maximum development of peat industry in the Center of Russia, as well as throughout the country, peat bogs with large peat reserves were assigned to industrial enterprises, and the remaining bogs were assigned to agricultural enterprises or forestries. These enterprises, at first, industrial, had their own fire fighting services, which monitored the entrusted territory and reacted quickly to signs of fires. In addition, all enterprises in their territory were obliged to maintain engineering systems for land-reclamation of bogs in working order, and for large peatlands which spread for several administrative districts, unified hydraulic engineering systems were designed and built (Marshev, 2011)

However, even then the problem was created by abandoned peat-extraction and drained peatlands. This problem manifested disastrously in the abnormally hot summer of 1972 , demonstrating the vulnerability of such territories to sharp weather and climate fluctuations. In 1972, 3088 forest and peat fires were recorded in the Moscow suburbs on the area of 32,900 hectares. 104 people died, 650 thousand hectares of forest suffered. A dangerous situation developed in the eastern, main peat-producing areas of the Moscow region, where there are large peat deposits and peat extraction enterprises are concentrated. In the fight against fires, almost 15 thousand self-propelled earth-moving machines and more than 2,500 thousand fire trucks and pumping devices took part, which worked continuously for 14-20 hours a day. The fires were liquidated by September 10 (Information on peatland fires in Moscow oblast, 2017).

In the post-Soviet period in conditions of system crisis after the collapse of the USSR in 1991, only in the Moscow region thousands of hectares of former peat extraction lands were abandoned (Fig. 3). Their engineering infrastructure has been completely destroyed, driveways are broken or flooded (Marshev, 2011). This situation sharply increased the dependence of the stability of all 
areas of the Central Russia with the spread of peatlands from harsh weather and climate fluctuations, primarily in long periods of dry and hot weather in summer. The results were not long to appear.

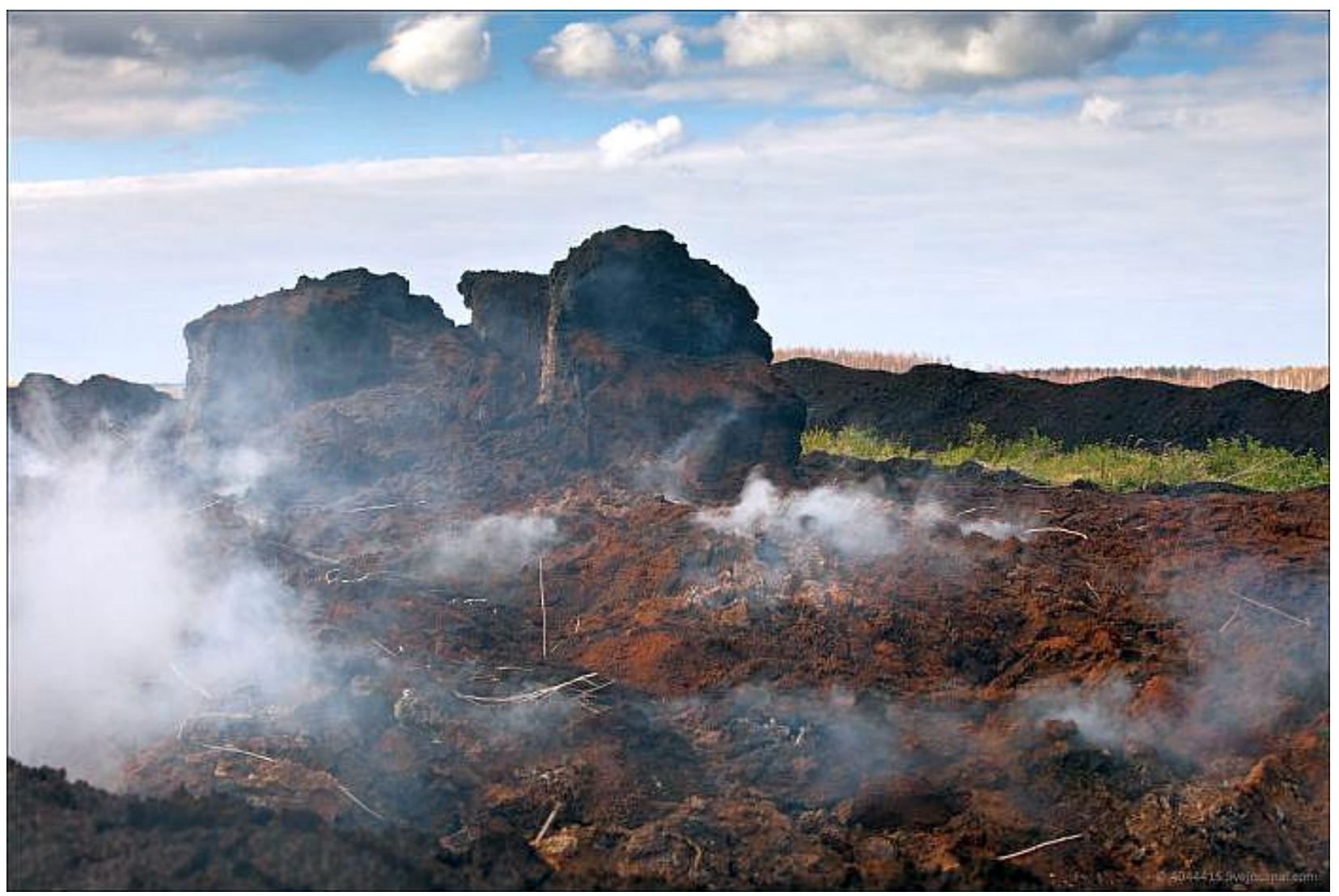

Fig 3. Abandoned peatland. Source: http://trinixy.ru/63113-zabroshennye-torfyaniki-v-moskovskoj-oblasti-30.html

Already in spring and summer of 1992 in the Moscow oblast there were 1,198 hotbeds of forest fire on a total area of 2,300 hectares. Over 1200 hectares of forest were destroyed by fire. Dozens of towns and rural settlements were in smoky zones. A serious fire hazard situation developed in the region in August-September 2002. In the extreme eastern Shatura district, where peat extraction was conducted for 80 years, the village Shiryaevo was burnt. 23 municipalities suffered in varying degrees. In total, 2046 fires with a total area of 3 thousand hectares arose in the region. Fires from the distant areas of the Moscow region reached the capital and raged in the immediate vicinity of the Moscow Ring Road, caused an intense smoke in Moscow, which lasted from the end of August till September 10, although in Moscow the first serious smoke was observed at the end of July, but it was relatively short-lived (Information on peatland fires in Moscow oblast, 2017).

The fire hazard areas of the Moscow oblast are shown at the Fig. 4. They are located mainly in the east and the north and are associated with the spread of former and often now abandoned peat-extraction lands. We can also see areas on the extreme south of the region, not related to peat extraction, located on gray forest soils. However, the deep cause of their fire hazard is the same as in the east and north - it is an economic structural crisis, in this case, agriculture. And the reason for the fires here was very common in 2010 in Russia - it's fires on abandoned fallow lands covered with tall weeds. This danger does not exist where there is no abandoned land. For example, in 2010, in the southernmost chernozem (black-earth) Belgorod oblast with developed agriculture where it is abnormally hot, there was not one fire (Losev, 2012). 


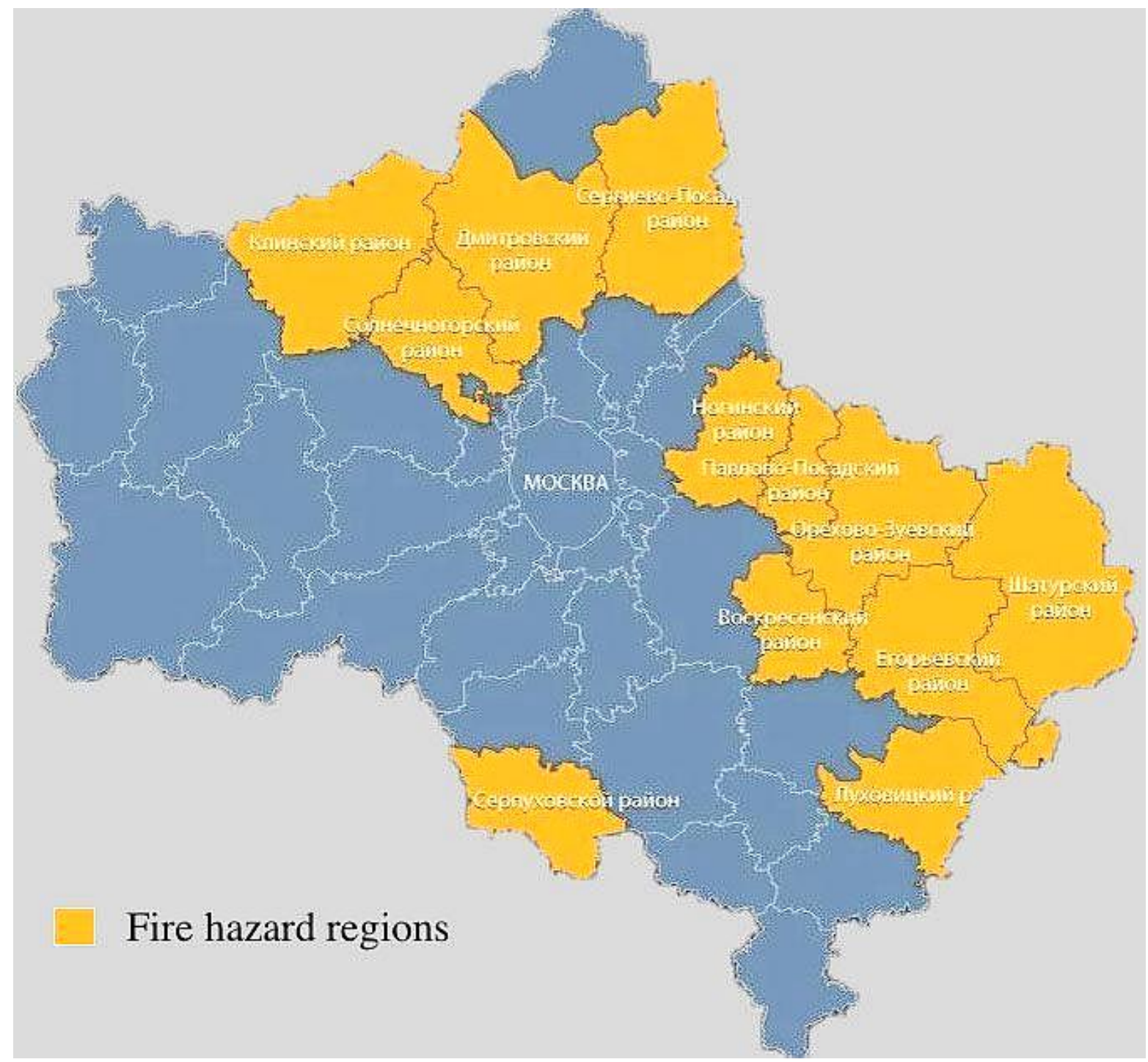

Fig 4. Fire hazard districts of the Moscow oblast. Source: Marshev (2011)

Peat fires were recorded in the Moscow region in early July 2010 (Fig. 5.). Forest and peat fires threatened 400 settlements, as well as 800 kilometers of communication and power transmission lines, 600 kilometers of railways, 800 kilometers of regional and federal roads (Information on peatland fires in Moscow oblast, 2017). As in 2002, long lasting smoke reached the center of Moscow (Fig. 6).

After the fires of 2010 , the regional authorities could no longer ignore the problem of abandoned peat-extraction lands and their failed land-reclamation infrastructure. So from the end of 2010, the development of project documentation for irrigation of Moscow Region peatlands began. The general concept of the system is the return of the natural regime of functioning to the territories of Moscow peat-extraction lands: restore of the natural processes of the bogs functioning by watering and cutting off the flow from the territories around settlements. Preference is given to individual solutions of local project tasks. The system includes hydraulic structures and canals. In total, it is necessary to restore step by step the natural regime of functioning of 77 thousand hectares of land in the Moscow Region, the total area of actions in 2011 can be seen in Fig. 7. In parallel, the order of administration of former peat-extraction land is regulated: a special regional enterprise is engaged in the operation of hydraulic facilities, forest lands go under control of Federal Forestry Agency, and the lands of the settlements - under control of the Moscow oblast authorities (Marshev, 2011). 


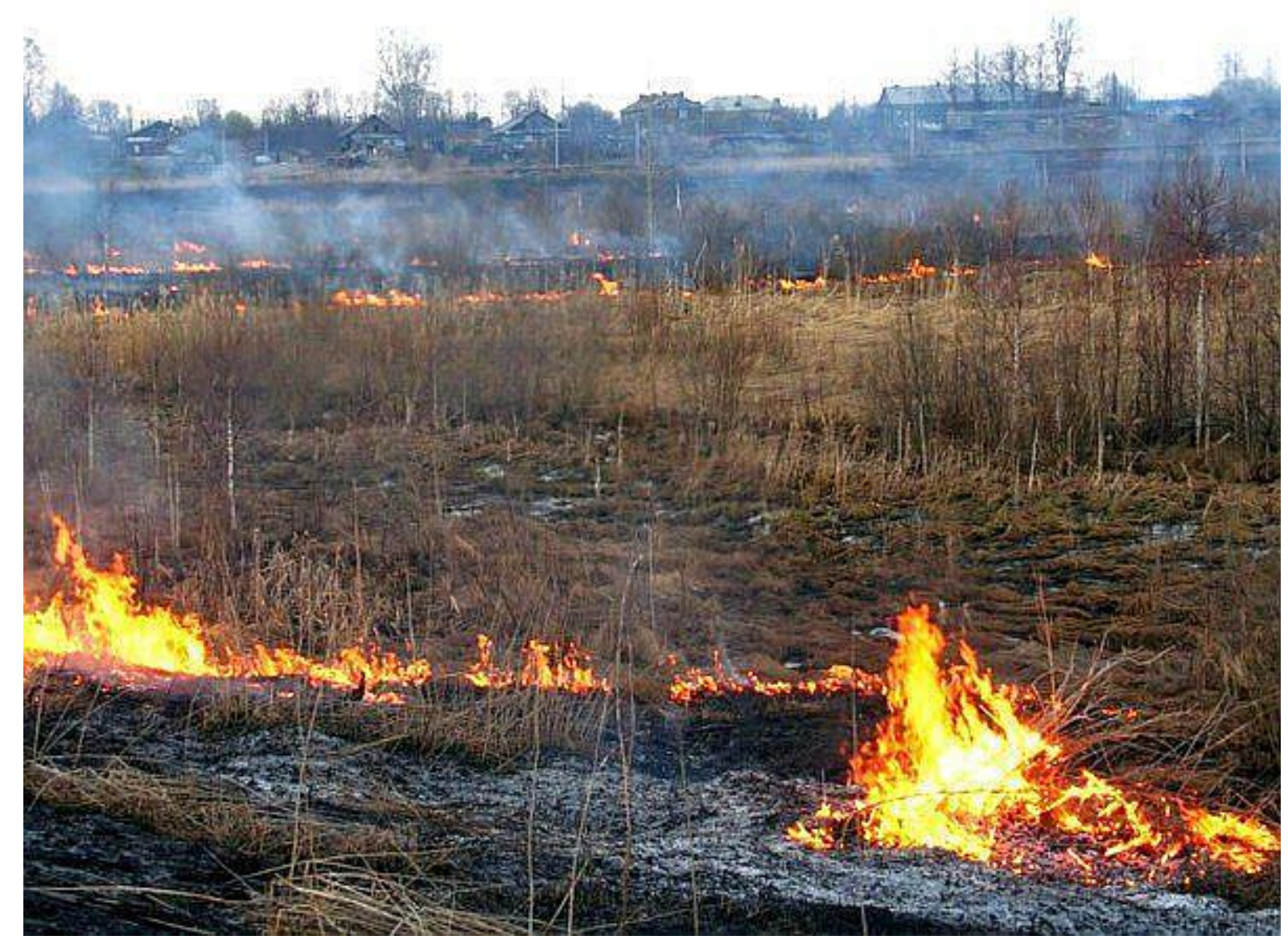

Fig 5. Peatland fire.

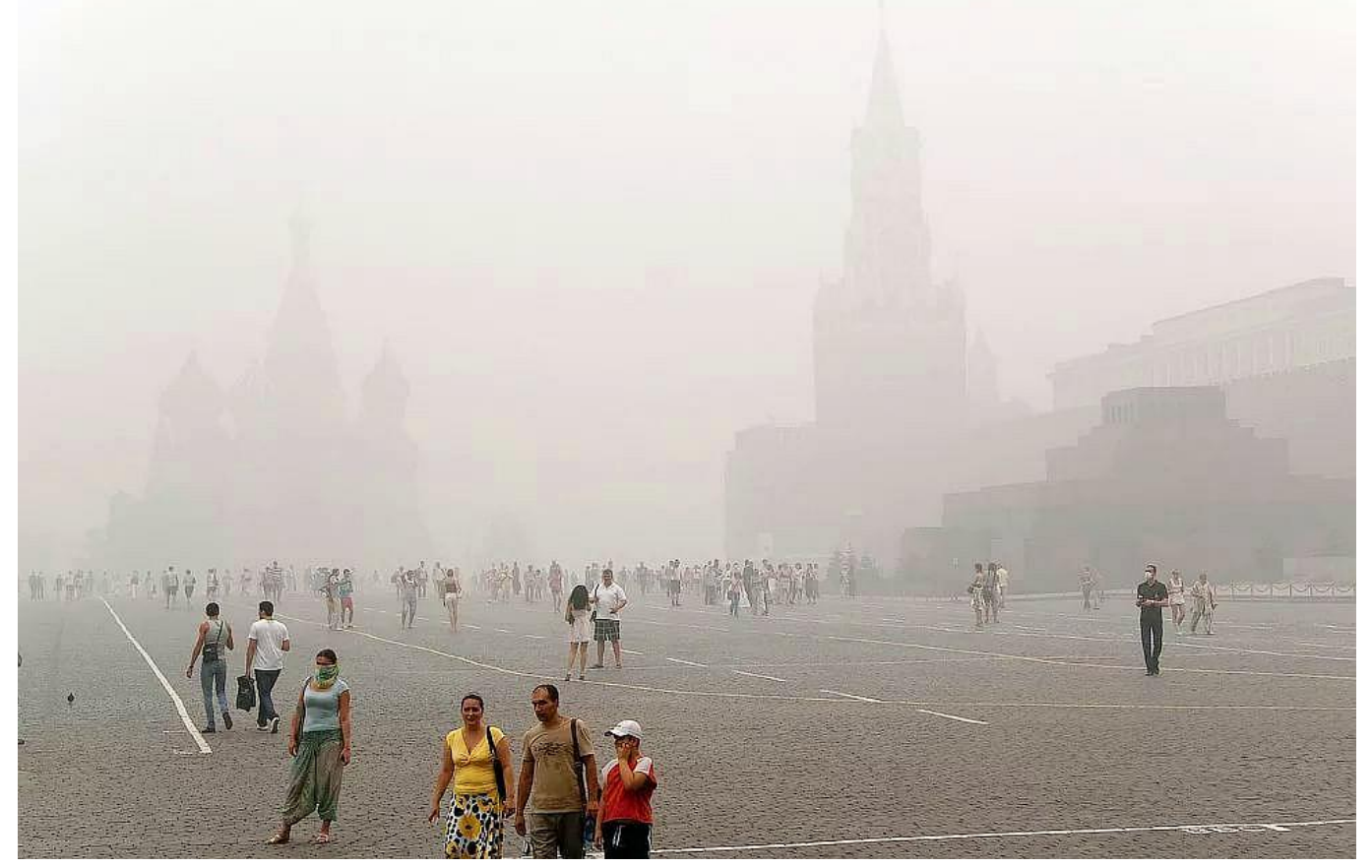

Fig 6. Smog in Moscow in summer, 2010. 


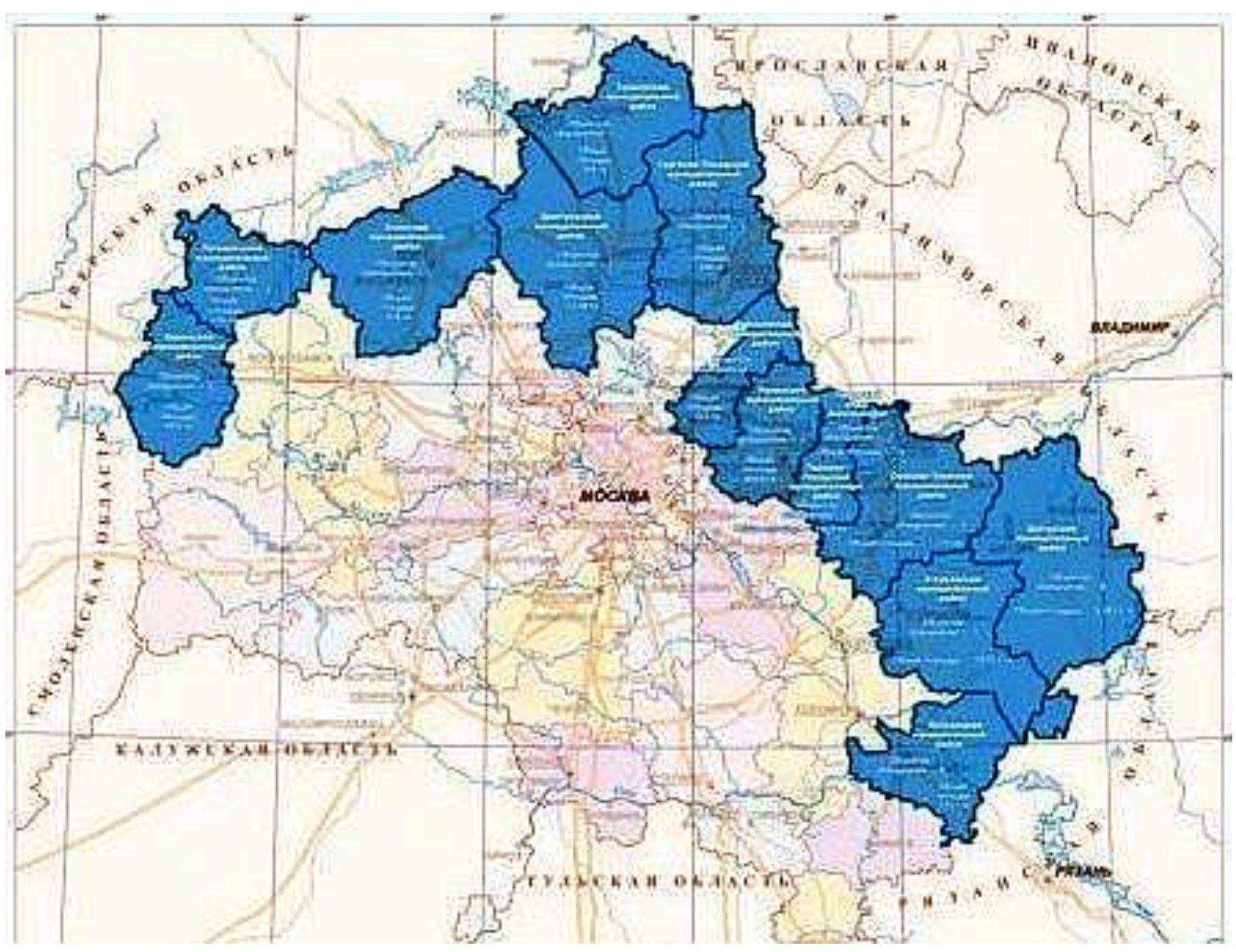

Fig 7. The districts of the Moscow oblast, where a program of peatland irrigation was implemented in 2011. Source: Marshev, 2011

Peat fires are the problem in other parts of the world, including Indonesia. Vast and disastrous fires occurred on Borneo during the 2015 dry season, pushing Indonesia into the top five carbon emitting countries. The region was affected by a very strong El Niño-Southern Oscillation (ENSO) climate phenomenon, on par with the last severe event in 1997/98. (Detection and Characterization..., 2015).

\section{Post-industrial transformation}

With the stoppage of large-scale peat extraction (due to the ineffectiveness of peat energy use) and the large-scale land-reclamation work in the areas of the most intensive peat extraction for returning these areas to the territories of the natural mode of life, new opportunities for improving the quality of life of rural settlements on peatlands are opened. These opportunities are again connected with Moscow, but this time it is about changing the features and direction of seasonal migration in the Moscow region in accordance with the requests of the post-industrial era.

Moscow and the Moscow oblast are the most populated regions in Russia (Table 1). Moscow and its agglomeration are unique for Russia due to a number of features, especially its power and importance.

Tab 1. Population of Moscow and the Moscow oblast, 2017. Source: Federal State Statistics Service

\begin{tabular}{|l|c|c|l|}
\hline \multicolumn{5}{|c|}{ Population 01.01.2017 (thousand) } \\
\hline & total & urban & rural \\
\hline Moscow & $12,380.7$ & $12,228.7$ & 152.0 \\
\hline Moscow oblast & $7,423.5$ & $6,063.0$ & $1,360.5$ \\
\hline
\end{tabular}


In the late Soviet period, a considerable part of the Moscow agglomeration evolved as a major scientific and industrial center, which included science cities and cities of the military-industrial complex. The conditions of Moscow's transformation in the post-Soviet period were determined by the established in the Soviet period spatial structure, which has received a strong push for development due to changes in the institutional conditions: real estate and land markets have been formed, the employment pattern has changed, the gap in living standards with other regions has led to increased migration inflow, a rental type economy has formed. During the 1990s2000s, the processes of commuting between cities of the Moscow region and Moscow have been intensifying; a common labor market of the Moscow region has formed. The nearest suburbs have morphologically merged with Moscow and formed a continuous urbanized area.

At present, the Moscow agglomeration has a postindustrial type of development, which is conditioned by the overconcentration of management functions in the capital, as well as financial and demographic resources and technological and social innovations. Services and trade are developing at a fast pace, and in the 1990s-2000s. In the post-Soviet period, the Moscow agglomeration continued inertial monocentric development, retaining the trends of core compaction, complication of structure, and expansion of the core at the expense of the suburbs (Kuricheva, Popov, 2016) (Fig. 8, Fig. 9).

In Fig. 8, the blue line shows the limits of the contemporary Moscow agglomeration, the red line - outer boundary of Moscow oblast, the violet line - prospective Moscow agglomeration, and lines of the second-category agglomerations around cities in Moscow oblast and neighboring oblasts.

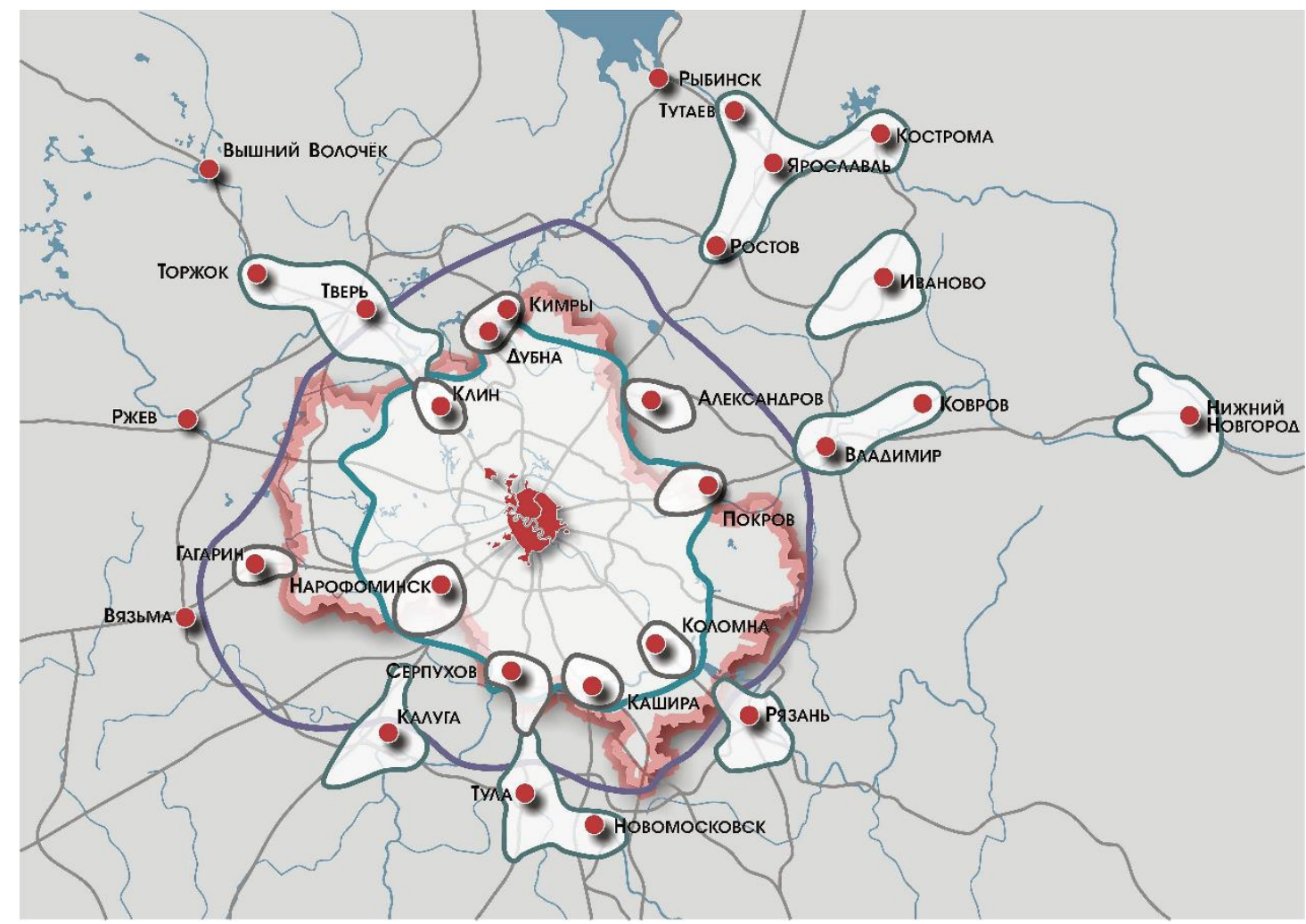

Fig 8. The scheme of the Moscow urbanized region. Source: Makhrova et al, 2013 


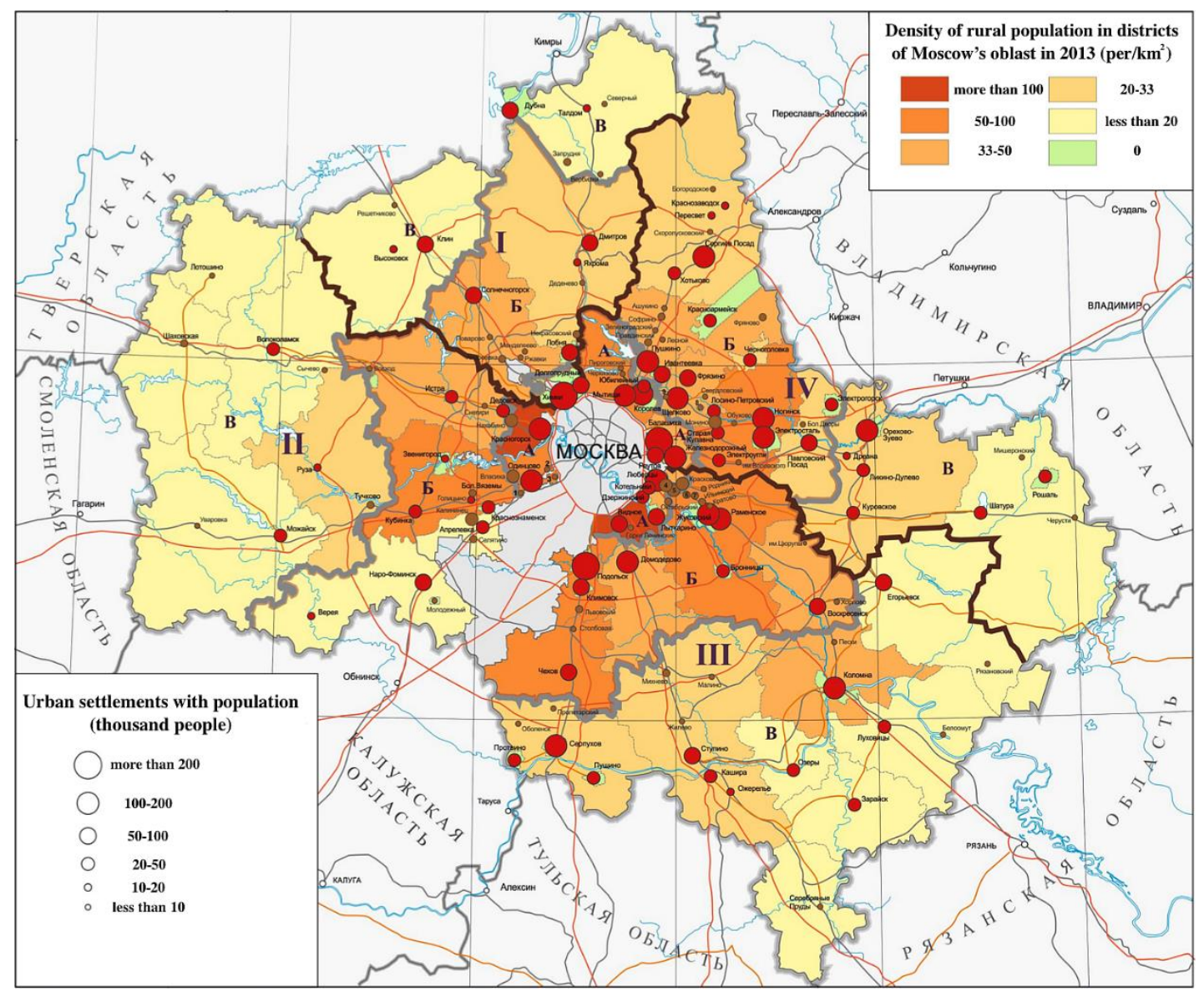

Fig 9. Population of the Moscow oblast. Source: Savchenko, 2013

Seasonal dacha migration determines the specifics of suburbanization in the Moscow agglomeration: over 3 million Muscovites have dachas, and over half a million own all-season suburban homes, but the scales of living in the suburbs on a regular basis are still much lower. The dominance of the recreational function of dachas over a permanent residence function confirms the retention of the traditional model of living at dachas on the weekend regardless of season, though the farther the distance from Moscow, the less people go there during all seasons (Makhrova, Kirillov, 2016).

Various types of Russian dachas (seasonal country house) can be found in Moscow region. These are old houses built in the early or mid- $20^{\text {th }}$ century, garden-orchard communities, country houses purchased or inherited by urban dwellers, and newly-built cottages, integrated into garden-dacha developed areas or organized as separate townships. Different types are characterized by different location. Old dachas tend to concentrate within the strip of the near and medium-distance suburbs. Garden communities with cheaper houses are spread within the medium-distance and distant areas.

In the peripheral districts of the Moscow oblast and adjacent areas of neighboring oblasts with less population density, seasonal summer population far exceeds the number of permanent residents (Fig. 10). 


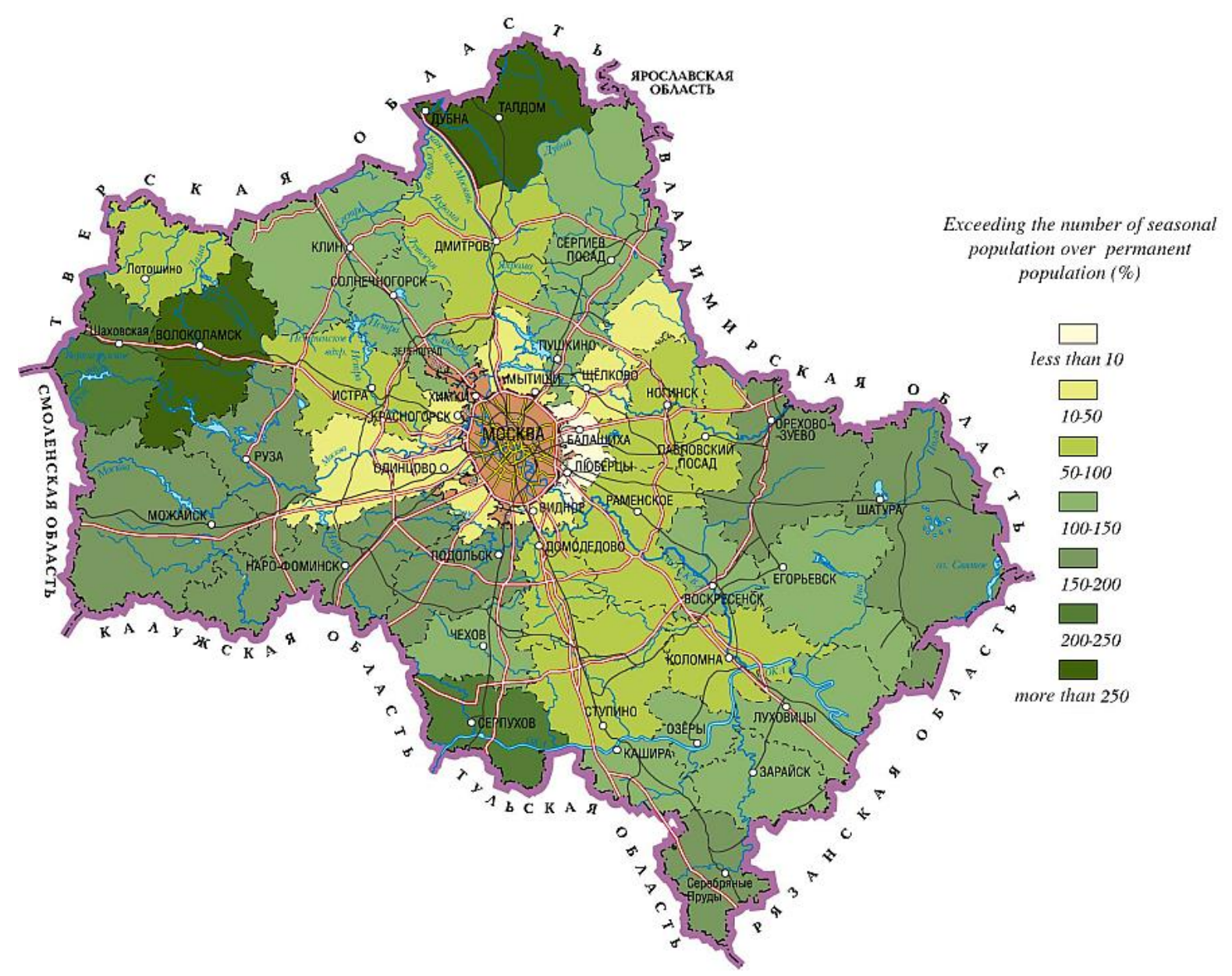

Fig 10. Exceeding the number of seasonal population over permanent population. Source: Makhrova, 2015

\section{Case-study: Klin and Konakovo districts}

Let's take the example of areas adjacent to the highway Moscow-St.-Petersburg: the Klin district of the Moscow oblast and neighbouring Konakovo district of Tver oblast.

The construction in the middle of the 19th century and the maintenance of the Moscow-St. Petersburg railway caused the reduction of forests in a vast area around the line: at first, the wood went to engineering structures, then to firewood for locomotive furnaces. At the same time, the growing needs of developing industry, which needed additional energy, also required the wood. The expensiveness of wood and imported fuel forced to seek replacement, and from the end of the XIX century development of peatlands began in these regions.

The first peat for the boiler began to use the enterprises of the Moscow region. Alferov's peatextraction enterprises of the Klin district supplied the Vysokovsk spinning and weaving factory from the 1890s, as well as the peatland "Galitsky moss", where peat went to the porcelain factory of Matvey Kuznetsov in the village Kuznetsovo (now Konakovo). Since the 1890s, the textile factories of Tver and the glassworks of Vyshny Volochok passed to peat. Peat extraction, which required a large number of workers, led to the creation of fairly large "peat" villages with their infrastructure. Peat briquetting plants were built, narrow-gauge railways were supplied. In 1902, in the village Redkino (now Konakovo district of the Tver oblast) the first peat-chemical plant in Russia was created, where peat coke and various chemical compounds were produced. In the early years of Soviet period in the 1920s, under conditions of transport disruption and fuel shortage, peat became the basis of local electric power industry, the first power stations in Tver and other cities worked on peat. Peat enterprises also developed during the Great Patriotic War of 1941-1945, and after it, peat was gradually forced out of the fuel balance by coal and hydrocarbons. Peat enterprises retired from the economy of their regions long and gradually, as peat was replaced by fuel oil and natural gas in local boilers. Peat may still be needed as an "eco- 
material" for construction and in a new over-intensive agriculture, but so far the once powerful peat industry in these areas has frozen in expectation of changes (Nefedova, T. \& Treivish, A., eds., 2015).

Peat extraction is a process that requires constant monitoring of the natural environment. Waste peatlands require recultivation and watering, otherwise they will become fire hazardous. Traces of old peat extraction are visible on maps and satellite photographs until now. The main legacy of peat cultivation in addition to disturbed bog ecosystems are settlements. In the 1950s in the settlements where peat was extracted, apartment houses and infrastructure facilities were built. Peat reserves were calculated for half a century or more, so housing was not considered as temporary. Now most of these settlements have from 500 to 2,000 inhabitants. Such large rural settlements are a rarity for the Non-Black Earth Region with usually small dispersed rural settlements. At the same time, due to their monospecialization, they do not become service centers, they rarely acquire new functions, becoming "pensioners villages" and centers of "otkhodnichestvo" of the working population. Often, they are the most problematic in their regions. At the same time, the social and economic situation of such settlements strongly depends on their geographical location. Konakovo district of the Tver region, located in the peripheral zone of the Moscow agglomeration, is also suburban for the regional center Tver.

The peculiarity of this territory is that it is the closest to Moscow "Great Water." - Volga River and Ivankovo Reservoir, otherwise called Moscow Sea. Here is also the governmental residence Zavidovo. Now, this is what determines the development of these districts. Area along the banks of the Volga becomes a zone of the elite recreation. Along with old garden - orchard settlements cottage settlements with very expensive villas develop here. A few years ago a project Great Zavidovo began to develop. A golf club and a championship golf course, the hotel "Radisson", marina area for yachts are already built, Houses are built in various price categories - from apartment buildings and modest houses on plots of 6 acres (although their minimum cost 6 million rubles.) to luxury villas around the golf course. In the future, the developers plan to construct a city here with a population of 30 thousand people, university with campus, environmentally friendly industrial enterprises, industrial parks, etc. It will really be the conjunction of the Moscow and Tver agglomerations. Implementation of this project is impossible without construction of a new high-speed highway. Now it takes 5-6 hours to get here from Moscow through traffic jams, which kills any rest.

The settlement Radchenko, where the institute of peat and peat-chemical plant earlier were situated, changed its specialization and develops together with a nearby settlement Redkino as a center of the production of modern building materials and parts. But now mostly dacha settlements are located on the former peatlands. In the conditions of depopulation and mass outflow of the rural population, the number of summer residents here is much higher than the number of the permanent rural population. Currently, in Konakovo district, about 18,000 permanent residents live in rural settlements, and there are 134 dacha settlements (in the status of orchard communities) in which there are more than 30,000 plots. So, for example, in the territory of the Vakhonino rural municipality (permanent rural population - 1.5 thousand people) near the railway station Konakovsky Mokh (mokh is the moss in Russian), there are 28 orchard communities, which have more than 11 thousand plots (Fig. 11). And it is necessary to add to them dachniks who bought houses in the villages. In the villages along the banks of the Volga, almost all the houses are bought by Muscovites and used as dachas. Thus, in summer there can be up to 40-50 thousand seasonal population (Fig. 12) (Nefedova, T. \& Averkieva, K, eds., 2015). 


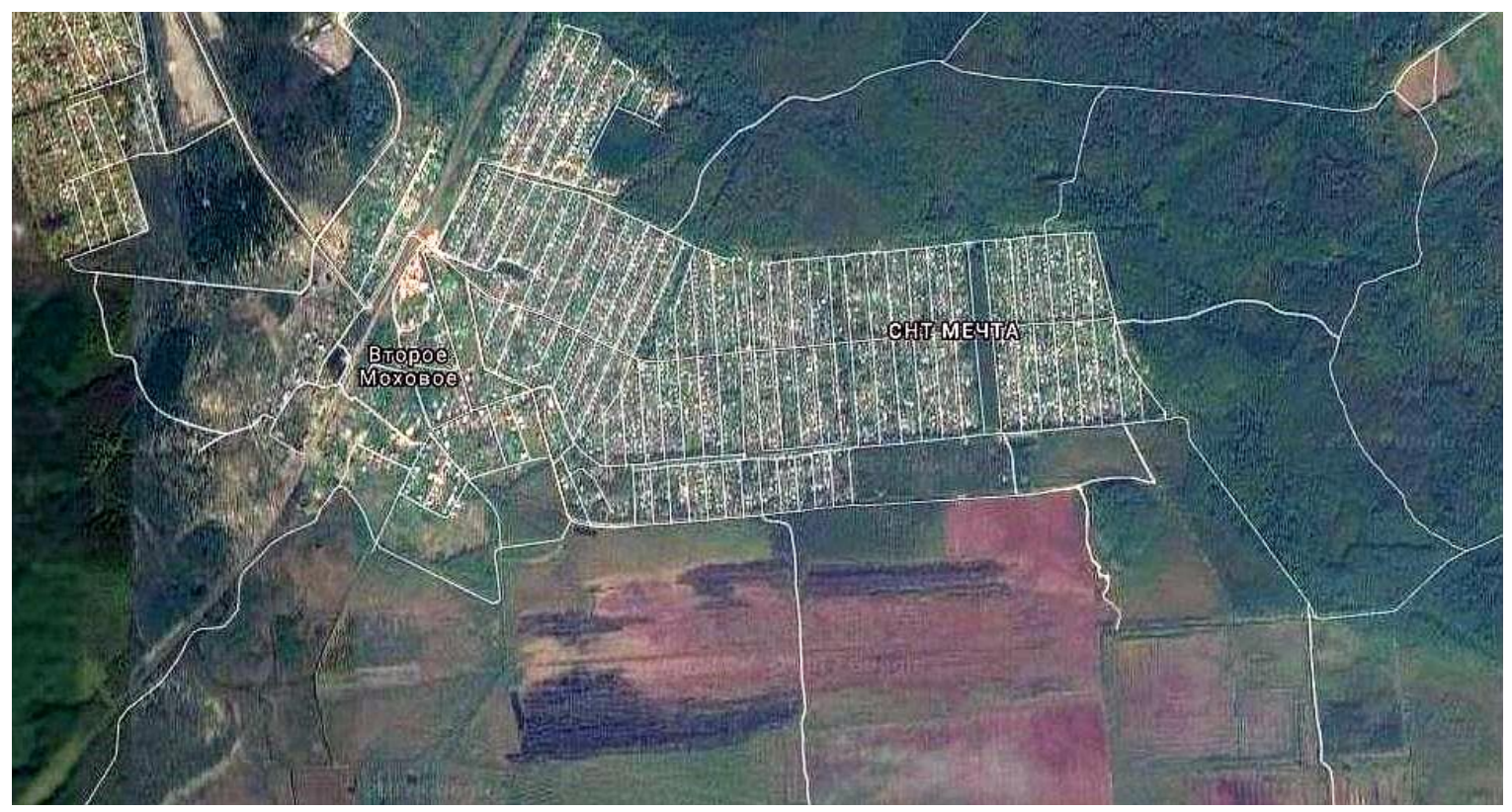

Fig 11. Satellite photograph of dacha settlement near the railway station Konakovskiy Mokh in Konakovo district, Tver oblast. Source: Google maps

At the same time, the territories of the former peat extraction are very vulnerable in ecological terms. In dry 2002 and 2010 the peatlands burned, the acrid smoke covered the whole neighborhood. This not only worsened the quality of life, but made living in dachas practically impossible. It should be noted that the majority of summer residents who live there all summer are the oldest and younger members of families - grandparents with grandchildren, i.e., the most vulnerable segments of the population in terms of health status. Earlier, on the abandoned peatlands, a lot of mushrooms and berries grew: blueberries, bilberries, cowberries and cranberries. "Mushroom forests" near the station Konakovsky Mokh were known to many Muscovites. In the mushroom season, not only dachnics went there, people came by train and by car from Moscow to pick mushrooms and berries. During the fires of 2002, the berry fields burned out, the popularity of this type of recreation was greatly reduced. Further development of these areas is impossible without maintaining ecological balance on peatlands.

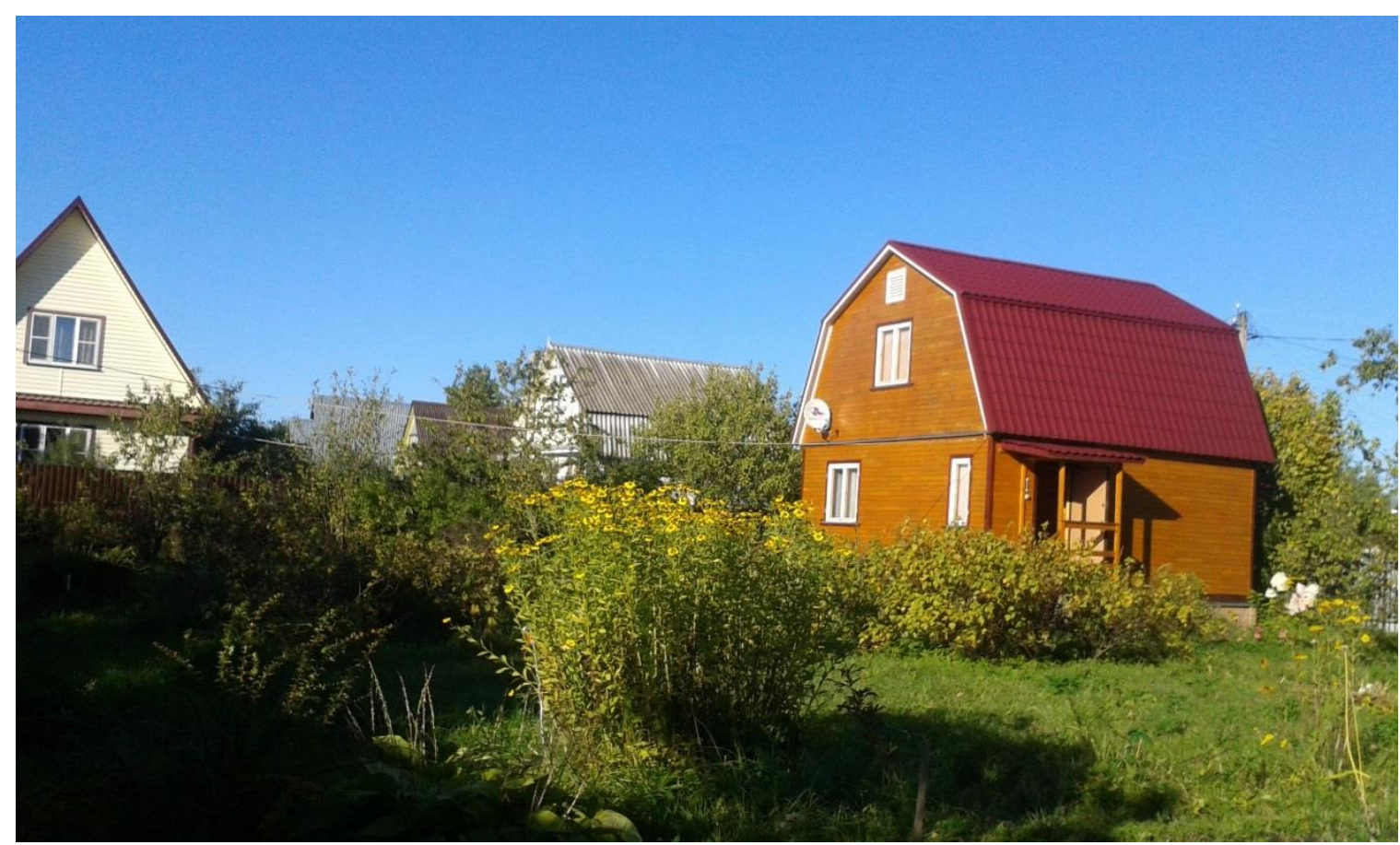

Fig 12. Orchard (dacha) settlement near the railway station Konakovskiy Mokh in Konakovo district, Tver oblast (Photo: T. Borodina, 2017) 
In Fig. 11 and Fig. 12 - dachas near the station Konakovsky Mokh. In this settlement, there are 2,500 plots with an area of 6 acres. In the late 1970s, these plots were given to employees of Konakovo enterprises, but now almost all of them are repurchased by Muscovites. Many families own 2-3 nearby plots, thus really own not 6, but 12-18 acres of land. At Fig. 11 to the south of the village, you can see former peat quarries. Black spots are traces of fires in 2002.

\section{Conclusion}

Excess moisture and low natural productivity of peatlands (in comparison with other common types of landscapes of the middle latitudes) impose severe restrictions on the number of agricultural population which can receive sufficient means of subsistence in these areas. This circumstance, at least since the 18th century, forced the population of rural settlements on peatlands to rely on external economic relations. In the Centre of Russia, Moscow has always been the center of attraction for neighboring territories, and an extensive and stable rural-urban continuum formed from this period.

Participation in labor and business relations with Moscow provided the population of settlements on peatlands not only of Moscow, but also of neighboring Tver, Yaroslavl and Vladimir regions, relatively high incomes and led to an improvement in the quality of life in these settlements. However, the development of industrialization rigidly subordinated the life of settlements on peatlands to the needs of Moscow and the nearest relatively small industrial towns. Population began (sometimes dramatically) to reduce and, on a mass scale, migrated to cities. In parallel, but slightly later, peatlands underwent a significant anthropogenic load, first associated with a sharp increase in the extraction of energy peat, then - with the abandonment of waste areas.

The latter critically increased the vulnerability of peatlands to fluctuations in weather and climate conditions and several times led to serious environmental disasters that not only worsened the quality of life of settlements on peatlands, but sometimes questioned their very existence.

At the same time, the location in the zone of Moscow's attraction opens up the possibility of improving the quality of life of settlements on peatlands. These opportunities are connected with the large-scale wave of recreational suburbanization that has been developing in the last 20 30 years.

\section{Acknowledgements}

The study was performed at the Institute of Geography, Russian Academy of Sciences, with financial support from the Russian Science Foundation, project number 16-17-10236 "The Impact of Climate Change on the Life Activity of the Population in Russia (Areas with Special Climatic Conditions)."

\section{Academic references}

[1] Boncinelli, F., Pagnotta, G., Riccioli, F. \& Casini, L. (2015). The Determinants of Quality of Life in Rural Areas from a Geographic Perspective: the case of Tuscany. Review of Urban \& Regional Development Studies, 27(2), 104-117. DOI: 10.1111/rurd.12035.

[2] Bonn, A., Allott, T., Evans, M., Joosten, H. \& Stoneman, R, eds. (2016). Peatland Restoration and Ecosystem Services: Science, Policy and Practice. Cambridge: Cambridge University Press. DOI: 10.1017/CBO9781139177788.

[3] Brade, I. \& Kovacs, Z. (2014). City and countryside under world-wide urbanization. Regional Research of Russia 4(2), 76-80. DOI: 10.1134/S2079970514020038.

[4] Brauer, R. \& Dymitrow, M. (2014). Quality of life in rural areas: A topic for the Rural Development policy? Bulletin of Geography. Socio-economic Series, 25, 25-54. DOI: $10.2478 /$ bog-2014-0028. 
[5] D'Agostini, L. R. \& Fantini, A. C. (2008). Quality of Life and Quality of Living Conditions in Rural Areas: Distinctively Perceived and Quantitatively Distinguished. Social Indicators Research 89, 487-499. DOI: 10.1007/s11205-008-9245-4.

[6] Fedorov, V. A. (1976). A peasant-otkhodnik in Moscow (the end of the XVIII - the first half of the XIX century). In Yanin, V. N., ed., Russkij gorod (pp. 165-180). Moscow: Izdatel'stvo moskovskogo universiteta.

[7] Gregory, D., Johnston, R., Pratt, G., Watts, M. \& Whatmore, S., eds. (2009). Dictionary of Human Geography (5 ${ }^{\text {th }}$ ed.). Oxford: Wiley-Blackwell.

[8] Kuricheva, E. K., Popov, A. A. (2016). Housing Construction Dynamics in the 2010s as a Factor of Transformation of the Moscow Agglomeration. Regional Research of Russia. 6(1), 9-20. DOI: 10.1134/S207997051601007X.

[9] Losev, K. S. (2012). Forest fires in Russia: a climatic or anthropogenic challenge? In Kotlyakov, V. M., ed., Vyzovy XXI veka: priroda, obshhestvo, prostranstvo. Otvet geografov stran SNG. (pp. 145-155). Moscow: Tovarishhestvo nauchnyh izdanij KMK.

[10] Makhrova, A. G. (2015). Seasonal suburbanization in the regions of Russia. Vestnik Moskovskogo universiteta Ser. 5. Geografija 4, 59-68.

[11] Makhrova, A. G., Kirillov, P. L. (2016). Seasonal Pulsation of Settlement Pattern in the Moscow Agglomeration under the Influence of Dacha and Work Commuting: Approaches to Studies and Assessment. Regional Research of Russia 6(1), 1-8. DOI: 10.1134/S2079970516010081.

[12] Makhrova, A. G., Nefedova, T. G. \& Treivish, A. G. (2013). Moscow Agglomeration and "New Moscow": The Capital City-Region Case of Russia's Urbanization. Regional Research of Russia. 3(2), 131-141. DOI: 10.1134/S2079970513020081.

[13] Marshev, S. V. (2011). Watering the territory of peat bogs in the Moscow region. Territorija I planirovanie. (34), 44-53.

[14] Nefedova, T. G. (2015). Migration Mobility of Population and Otkhodnichestvo in Modern Russia. Regional Research of Russia 5(3), 243-256. DOI: 10.1134/S2079970515030077.

[15] Nefedova, T. \& Treivish, A., eds. (2015). Puteshestvie iz Peterburga v Moskvu. 222 goda spustja. Kniga 1. Dva stoletija rossijskoj istorii mezhdu Moskvoj i Sankt-Peterburgom. Moscow: URSS-LENAND.

[16] Nefedova, T. \& Averkieva, K. eds. (2015). Puteshestvie iz Peterburga v Moskvu. 222 goda spustja. Kniga 2. Puteshestvie iz Peterburga v Moskvu v XXI veke (po itogam jekspedicii 2013 g.). Moscow: URSS-LENAND.

[17] Nussbaum, M. \& Sen, A., eds. (1993). The Quality of Life, Oxford: Clarendon Press.

[18] Pospěch, P., Delín, M. \& Spěšná, D. (2009). Quality of life in Czech rural areas. Agricultural Economics - Czech, 55(6), 284-295.

[19] Savchenko, A., ed. (2013). Moskva. Preemstvennost' v peremenah. 400 let gradostroitel'nyh planov Moskvy. Moscow: Genplan Institute.

[20] Serebryanikov, N. I. (1998). Moscow Power System. In Edinaja jenergeticheskaja sistema Rossii. Vospominanija starejshih jenergetikov (pp. 314-335). Moscow: Energoatomizdat.

[21] Shucksmith, M., Cameron, S., Merridew, T. \& Pichler, F. (2009). Urban-Rural Differences in Quality of Life across the European Union. Regional Studies, 43(10), 1275-1289. DOI: $10.1080 / 00343400802378750$.

[22] Sorokin, P. \& Zimmerman, C. (1929). Principles of rural-urban sociology. New York: Holt.

[23] Stiglitz, J., Sen, A., Fitoussi, J.-P., eds. (2009). Report by the Commission on the Measurement of Economic Performance and Social Progress. Template Lab. 
[24] Treivish, A. I. (2009). Gorod, rajon, strana i mir. Razvitie Rossii glazami stranoveda. Moscow: Novy Khronograf.

[25] Treivish, A. I. (2016). The rural-urban continuum: regional dimensions. In Kotlyakov, V. M., Streleckij, V. N., Glezer, O. B. \& Safronov, S. G., eds., Problemy regional'nogo razvitija Rossii (pp. 51-71). Moscow: Russian Geographical Society.

Other sources

[26] Better Life Index. Retrieved September 15, 2017, from http://www.oecdbetterlifeindex.org/\#/11111111111.

[27] Climate change blamed as EU's forest fires more than double. Retrieved October 16, 2017, from http://www.euronews.com/2017/10/16/how-europe-s-wildfires-have-more-than-trebledin-2017.

[28] Deadliest wildfires in California ever: lessons to be learned from southern Europe. Retrieved October 13, 2017, from https://www.climatechangepost.com/category/forest-fires-forestryand-peatlands/.

[29] Detection and Characterization of Low Temperature Peat Fires during the 2015 Fire Catastrophe in Indonesia Using a New High-Sensitivity Fire Monitoring Satellite Sensor (FireBird). Retrieved October 15, 2017, from http://europepmc.org/articles/pmc4972419.

[30] Fact Sheet EU Rural Development policy 2007-2013. European Commission, 2008. Brussels: European Commission directorate-General for agriculture and rural development.

[31] Federal State Statistics Service of Russian Federation. Retrieved September 10, 2017, from www.gks.ru.

[32] Human development index. Retrieved September 15, 2017, from http://hdr.undp.org/en/content/human-development-index-hdi.

[33] Life-2016. Retrieved September 15, 2017, from www.riarating.ru.

[34] Information on peatland fires in Moscow oblast. Retrieved September 25, 2017, from https://ria.ru/spravka/20100714/254723376.html.

[35] Quality of life indicators - measuring quality of life. Retrieved September 15, 2017, from http://ec.europa.eu/eurostat/statistics-explained/index.php/Quality_of_life_indicators__measuring_quality_of_life.

[36] Soviet encyclopedic dictionary, M.- Soviet Encyclopaedia, 1979): Sustainable development. Retrieved September 20, 2017, from http://sustainabledevelopment.un.org/sdgs.

[37] The Facts: Rural vs Urban Living in the UK. Retrieved October 15, 2017, from https://echochamber.club/facts-rural-vs-urban-living-uk/.

[38] Wildfires rip through southern and central Europe. Retrieved October 16, 2017, from http://news.sky.com/story/wildfires-rip-through-southern-and-central-europe-10952700. 